\title{
Cul4a as a New Interaction Protein of PARP1 Inhibits Oxidative Stress-Induced H9c2 Cell Apoptosis
}

\author{
Ning Ye, Naijin Zhang, Ying Zhang, Hao Qian, Boquan Wu, and Yingxian Sun \\ Department of Cardiovascular Medicine, The First Hospital of China Medical University, Shenyang 110001, China \\ Correspondence should be addressed to Yingxian Sun; yxsun@mail.cmu.edu.cn
}

Received 18 December 2018; Accepted 10 March 2019; Published 17 April 2019

Guest Editor: Sergey Bolevich

Copyright ( 2019 Ning Ye et al. This is an open access article distributed under the Creative Commons Attribution License, which permits unrestricted use, distribution, and reproduction in any medium, provided the original work is properly cited.

\begin{abstract}
Oxidative stress plays a major part in myocardial reperfusion injury. Cul4a is the core protein of CRLs E3 ubiquitin ligase complex; while it is known that Cul4a is responsible for various cancers, its role in cardiac function remains unclear. Hence, we have shown the protective function of Cul4a and its protection mechanism in oxidative stress-induced $\mathrm{H} 9 \mathrm{c} 2$ cardiomyocyte apoptosis. Here, oxidative stress was induced by hydrogen peroxide $\left(\mathrm{H}_{2} \mathrm{O}_{2}\right)$, CCK- 8 assay and flow cytometry were used to analyze cell viability and apoptosis rate, western blot and immunofluorescence were used to quantitatively analyze the expression of protein, ROS fluorescence kit was used to detect reactive oxygen species (ROS) formation, and coimmunoprecipitation was used to identify protein interaction. In the results, it was found that Cul4a was involved in oxidative stress-induced H9c2 cell apoptosis and could inhibit $\mathrm{H}_{2} \mathrm{O}_{2}$-induced ROS generation and $\mathrm{H} 9 \mathrm{c} 2$ cell apoptosis. Furthermore, we identified that when combining with PARP1, Cul4a could reduce its expression, and the interaction was enhanced under oxidative stress. In conclusion, our results indicate that Cul4a is a new protective factor involved in oxidative stress-induced cardiomyocyte injury and functions by tying and decreasing overactivated PARP1.
\end{abstract}

\section{Introduction}

Acute myocardial ischemia (AMI) is a main cause of death in China [1], and the most effective treatment is to perform myocardial reperfusion as soon as possible. However, this process can lead to myocardial cell dysfunction and apoptosis, which is called myocardial reperfusion injury [2]. Oxidative stress participates in the pathological process of nearly all cardiovascular diseases [3] and is crucial in myocardial reperfusion injury [4]. Therefore, exploring the mechanism of oxidative stress to alleviate myocardial cell damage is the key to the treatment of myocardial reperfusion injury.

PARP (poly ADP-ribose polymerase) is a DNA repair enzyme which is a cleavage substrate for caspase. It was considered to play an important role in DNA damage repair and apoptosis in the past. However, during oxidative stress, excessive activation of PARP1 can lead to depletion of ATP, which causes apoptosis [5]. Recently, several studies have also shown that PARP1 participates in oxidative stressrelated cardiovascular diseases, including ischemia reperfusion injury $[6,7]$. And the inhibitors of PARP1 can effectively relieve reperfusion injury in vivo experiment [8].

Cullin $4 \mathrm{a}(\mathrm{Cul} 4 \mathrm{a})$ is a $87 \mathrm{kDa}$ protein with a gene located at $13 q 34$ in the high expression region of the oncogene. It is a scaffold protein of the modular, multisubunit E3 ubiquitin ligase complex, which dynamically combines and degrades protein in a periodic manner [9]. Abnormal expression of Cul4a is closely related to various cancers [10]. Cul4a is involved in a series of processes such as cell cycle, DNA damage repair, histone methylation, signaling pathways, and oncoprotein transfer [11]. However, both the function of Cul4a in the cardiovascular disease and its role in myocardial injury caused by oxidative stress are still unclear.

Here, we describe a novel role for $\mathrm{Cul} 4 \mathrm{a}$ as a protector of myocardial cell apoptosis elicited by oxidative stress. Besides, Cul4a can reduce ROS generation, which is related to oxidative stress. We find that PARP1 is a new binding protein for Cul4a, and the mechanism that Cul4a can alleviate oxidative stress-induced cardiomyocyte injury may be associated with the degradation of overactivated PARP1. 


\section{Materials and Methods}

2.1. Cell Culture and Treatment. H9c2, a clonal heart muscle cell line, which was from the Cell Bank of the Chinese Academy of Sciences (Shanghai, China), was cultured in high glucose DMEM with 10\% FBS (GE Healthcare HyClone, USA) and $1 \%$ penicillin/streptomycin at $37^{\circ} \mathrm{C}$ in a $5 \% \mathrm{CO}_{2}$ incubator. Oxidative stress was induced by hydrogen peroxide $\left(\mathrm{H}_{2} \mathrm{O}_{2}\right)$; it is a recognized method.

2.2. Antibodies and Reagents. Antibodies to polyclone rabbit anticaspase3, monoclonal rabbit anti-PARP1, and mouse anti-Flag were obtained from Cell Signaling Technology (USA); polyclonal mouse anti-Cul4a, monoclonal rabbit anti- $\alpha$-tubulin, and anti-GAPDH were obtained from Proteintech (Wuhan, China). Protein A/G magnetic beads were acquired from Biotool (Shanghai, China).

2.3. RNA Interference and Gene Overexpression. For Cul4a knockdown, 70\% confluence H9c2 cardiomyocytes were transfected with control siRNA and Cul4a siRNA was provided by GenePharma (Shanghai, China). jetPRIME transfection reagent from PolyPlus (France) was used as the media to following the instructions. In order to preclude off-target effects, we synthesized three sequences and Western blot was used to ensure the efficiency of Cul4a knockdown. The target sequences were as follows: Cul4a siRNA1: GCCUAGAGCUGUUUAGGAATT, Cul4a siRNA-2: GCGAGUACAUCAAGACCUUTT, and Cul4a siRNA-3: GCUGCUAUAGUCAGAAUAATT.

For Cul4a overexpression, the H9c2 cardiomyocytes were transfected with pCDNA3.1-3×Flag or pCDNA3.1-Cul4aFlag provided by Sangon Biotech (China, Shanghai). Firstly, the medium was replaced with OPTI-MEM from Gibco (USA), after that, Lipofectamine 3000 from Invitrogen (USA) was used for transfection following the instructions.

2.4. Cell Viability Assay. Cell viability was calculated by Cell Counting Kit-8 (CCK-8) assay from Dojindo (Japan). The steps were as follows: cells were transfected in different groups for 48 hours, treated with normal media or $\mathrm{H}_{2} \mathrm{O}_{2}(50,100,200$, and $400 \mu \mathrm{M})$ in 2 hours, finally mixed with $100 \mu \mathrm{l}$ CCK-8 solution $(1: 10)$, and incubated for $1 \mathrm{~h}$ in $37^{\circ} \mathrm{C}$ after washing by PBS. Absorbance was measured at $450 \mathrm{~nm}$ by a microplate reader from Bio-Rad Laboratories (USA). Statistical software was used to calculate the cell survival viability.

2.5. Flow Cytometry Annexin-FITC/PI. Annexin Vfluorescein isothiocyanate (FITC) and propidium iodide (PI) assay were used to evaluate cell injury according to the instructions of the manufacturer. Cells were seeded in 6well plates, and different groups were transfected for 48 hours following the experimental requirements. After transfection, cells were treated with normal media or $\mathrm{H}_{2} \mathrm{O}_{2}(200 \mu \mathrm{M})$ for 2 hours. And then collecting cells, which were used by $0.25 \%$ trypsin without EDTA, were washed by PBS twice. Next, the cells were incubated in $500 \mu l$ binding buffer with $5 \mu \mathrm{l}$ Annexin $\mathrm{V}$ and $5 \mu \mathrm{l}$ PI solution for 30 minutes at room temperature in the dark. Finally, the cells were analyzed by the FACSCalibur flow cytometry with FL-1 and FL-2 channel.
2.6. Immunofluorescence Analysis. Cellular immunofluorescence was used following the well-established procedure. In short, the cells of different groups were washed with PBS, fixed with $4 \%$ paraformaldehyde, and handled with $1 \%$ Triton X-100 for 20 minutes. After blocking for 30 minutes, the cells were incubated with the primary antibody of Cul4a $(1: 200)$ for 4 hours in room temperature and then the fluorescent secondary antibody $(1: 200)$ provided by Life Technologies (USA) was added. The nucleus was stained with DAPI for 3 minutes avoiding lighting. Finally, the fluorescent microscope from Nikon Eclipse 90i (Japan) was used to visualize and capture images.

2.7. ROS Assay. ROS assay kit was obtained from Beyotime Biotechnology (Shanghai, China). According to the instructions, cells were transfected for 48 hours and then treated with various concentrations of $\mathrm{H}_{2} \mathrm{O}_{2}$ or PBS for 2 hours. After washing with PBS, the cells were suspended in $500 \mu \mathrm{l}$ serum-free medium with 2,7-DCFH-DA $(10 \mathrm{mM})$ for $60 \mathrm{~min}$ avoiding lighting, after which the cells were cleaned again with the same medium. The cells were excited at $488 \mathrm{~nm}$, and the image was visualized at $525 \mathrm{~nm}$ using fluorescence microscopy from Olympus (Japan).

2.8. Protein Preparation. For protein preparation, the cells were lysed with cell lysates buffer $(50 \mathrm{mM}$ Tris, $137 \mathrm{mM}$ $\mathrm{NaCl}, 1 \mathrm{mM}$ EDTA, $10 \mathrm{mM} \mathrm{NaF}, 0.1 \mathrm{mM} \mathrm{Na}$ VO $4,1 \% \mathrm{NP}-$ 40, 1 mM DTT, 10\% glycerol, pH 7.8, with protease inhibitors provided by Roche (Switzerland)) and then centrifuged at $12000 \mathrm{rpm} / \mathrm{min}$ for 15 minutes at low temperature. And then protein quantification was used by BCA to ensure $40 \mu \mathrm{g}$ total protein in each sample.

2.9. Coimmunoprecipitation. For immunoprecipitation, after washing twice by PBS, H9c2 cardiomyocytes were lysed with flag lysis buffer. The lysates were mixed with relevant antibody and $30 \mu \mathrm{l}$ of magnetic beads for a night. Next, the mixture was washed with lysate and dissolved to $20 \mu \mathrm{l} 2 \times \mathrm{SDS}$ PAGE.

2.10. Western Blot Analysis. Firstly, protein samples were separated on $10 \%$ SDS polyacrylamide gel electrophoresis. And then, PVDF membranes provide by Millipore (USA) were used to transfer. After transferring, the membranes were blocked in TBS/T buffer with 5\% BSA at room temperature. Finally, the membranes were put in to TBS/T buffer with $1 \%$ BSA, which diluted primary antibodies at $1: 1000$ in $4^{\circ} \mathrm{C}$ overnight. Next, the membranes were incubated with the diluted second antibody at 1:5000 for 2 hours homeothermy. After washing with TBS/T buffer for 45 minutes, the membranes were visualized and captured using enhanced chemiluminescence. Relative band intensity to control was measured by ImageJ software 1.46 (USA).

2.11. Statistical Analysis. All data reported was in the form of mean \pm standard deviation and analyzed with Student's $t$-test or one-way analysis of variance (ANOVA), which was performed using SPSS 22.0 statistical software (USA). Values were considered significant as $p<0.05$. 


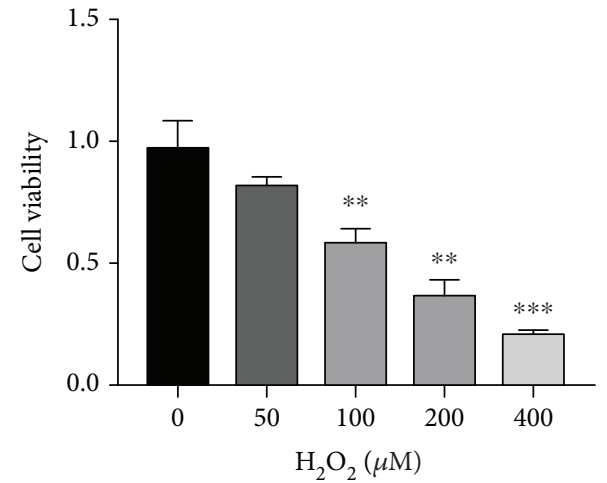

(a)
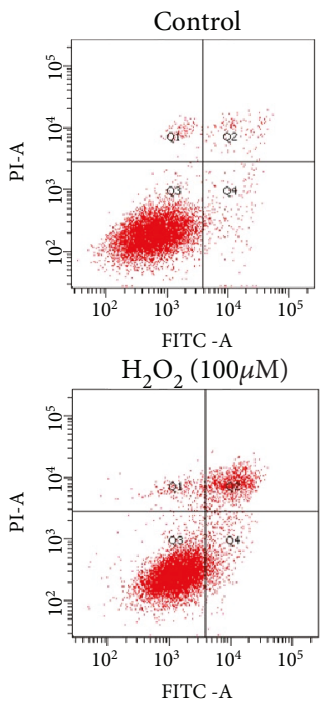$$
\text { 要 }
$$
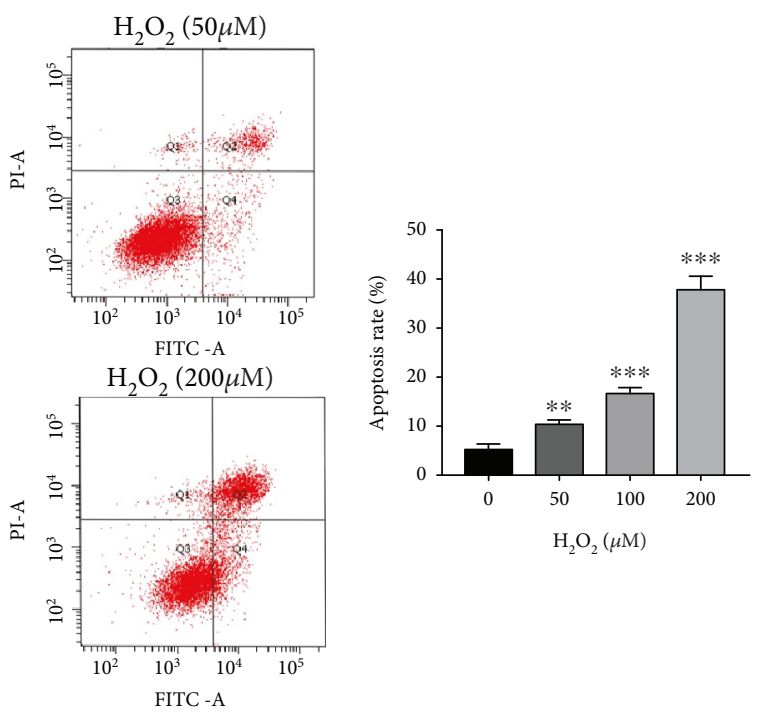

(b)

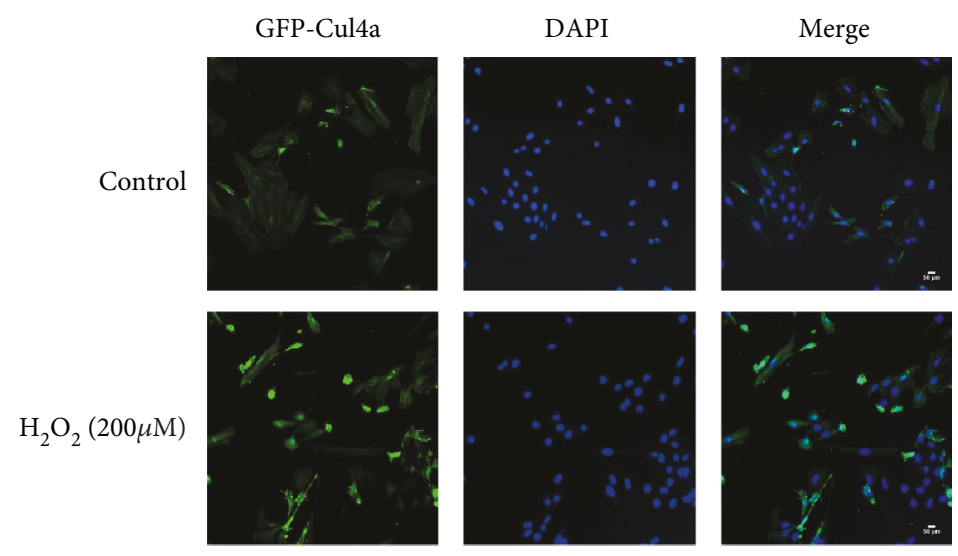

(c)
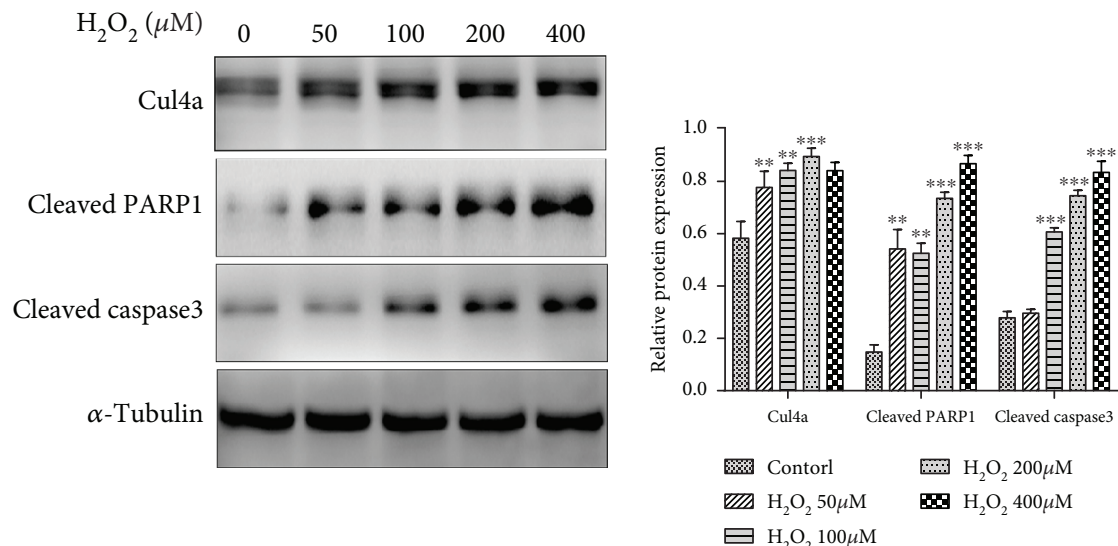

(d)

Figure 1: $\mathrm{H}_{2} \mathrm{O}_{2}$ increased Cul4a and apoptosis-related protein and decreased the viability of H9c2 cardiomyocytes. (a) H9c2 cells were untreated or treated with $50 \mu \mathrm{M}, 100 \mu \mathrm{M}, 200 \mu \mathrm{M}$, and $400 \mu \mathrm{M} \mathrm{H}_{2} \mathrm{O}_{2}$ for $2 \mathrm{~h}$. Cell viability was assessed by CCK-8 assay. (b) Flow cytometry Annexin-FITC/PI showed that the apoptosis rate of cell increased gradually induced by gradient concentration of $\mathrm{H}_{2} \mathrm{O}_{2}$. (c) Immunofluorescence staining of $\mathrm{H} 9 \mathrm{c} 2$ with Cul4a antibody (green) and DAPI for nuclei (blue) after treatment with $200 \mu \mathrm{M}$ of $\mathrm{H}_{2} \mathrm{O}_{2}$ for $2 \mathrm{~h}$. (d) Western blot analysis of Cul4a, cleaved PARP1 and cleaved caspase 3 expression after incubation with $\mathrm{H}_{2} \mathrm{O}_{2}(50 \mu \mathrm{M}, 100 \mu \mathrm{M}$, $200 \mu \mathrm{M}$, and $400 \mu \mathrm{M})$ for $2 \mathrm{~h}$; $\alpha$-tubulin was used as a loading control. ${ }^{* * *} p<0.001,{ }^{* *} p<0.01,{ }^{*} p<0.05$; scale bar, $50 \mu \mathrm{m}$. Data was expressed as means $\pm \mathrm{SD}$. 


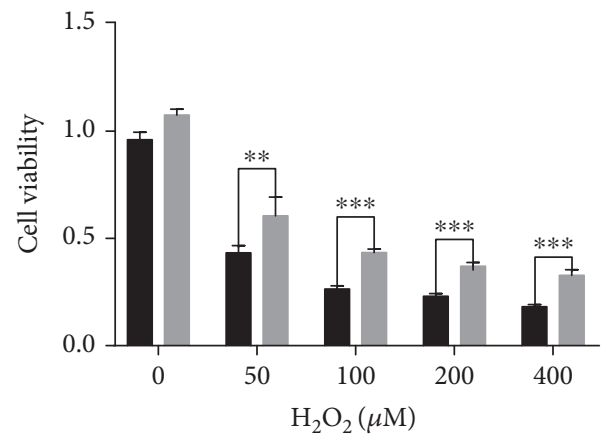

Vector

Flag-cul4a

(a)
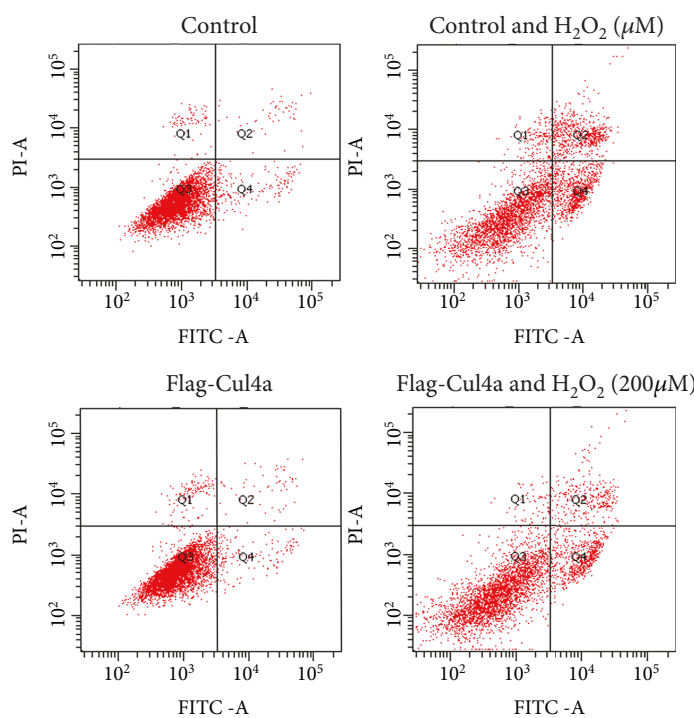

Flag-Cul4a and $\mathrm{H}_{2} \mathrm{O}_{2}(200 \mu \mathrm{M})$
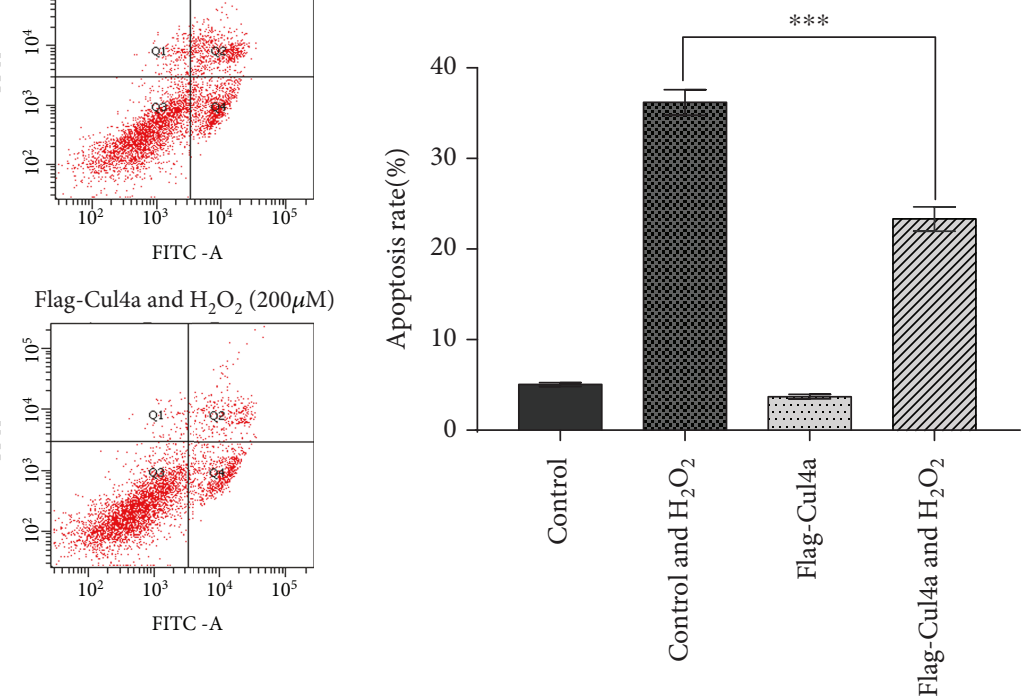

(b)
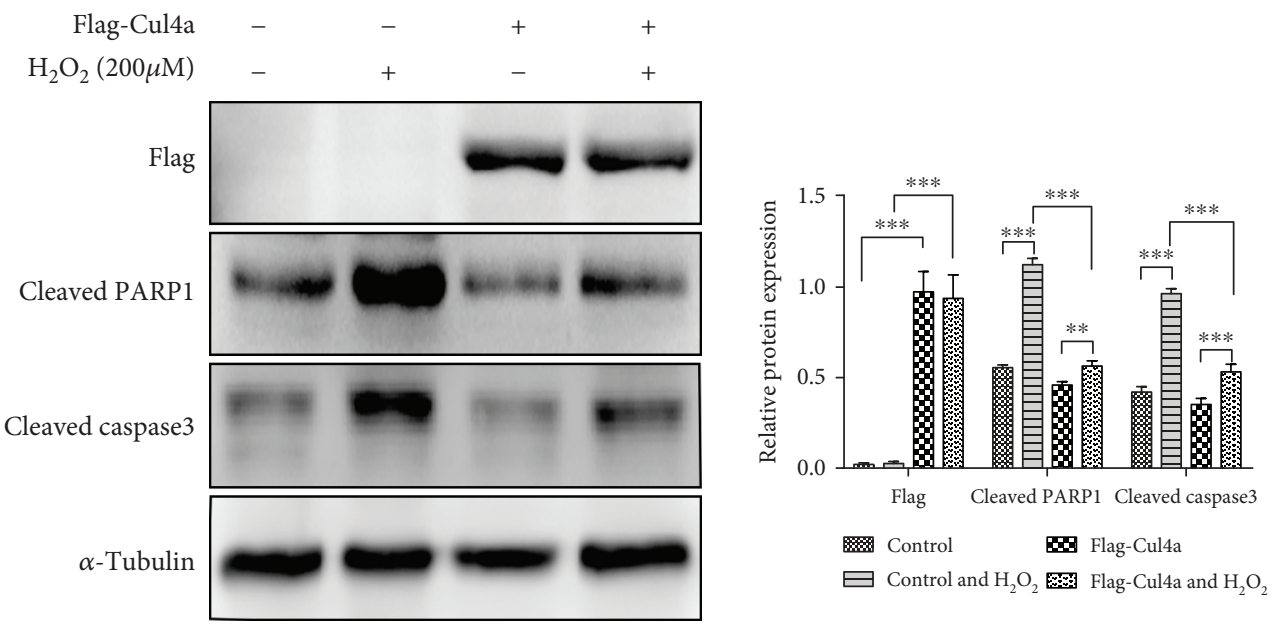

(c)

FIGURE 2: Cul4a overexpression inhibited $\mathrm{H}_{2} \mathrm{O}_{2}$-induced cardiomyocyte apoptosis. (a) $\mathrm{H} 9 \mathrm{c} 2$ cells were untreated or treated with $50 \mu \mathrm{M}$, $100 \mu \mathrm{M}, 200 \mu \mathrm{M}$, and $400 \mu \mathrm{M} \mathrm{H} \mathrm{H}_{2} \mathrm{O}_{2}$ for $2 \mathrm{~h}$. CCK-8 assay results showed that overexpressed Cul4a decreased $\mathrm{H}_{2} \mathrm{O}_{2}$-induced cell cytotoxicity. (b) Flow cytometry Annexin-FITC/PI showed that overexpressed Cul4a reduced $\mathrm{H}_{2} \mathrm{O}_{2}$-induced cell apoptosis. (c) Overexpressed Cul4a significantly decreased $\mathrm{H}_{2} \mathrm{O}_{2}$-induced apoptotic marker proteins cleaved PARP1 and cleaved caspase- 3 expression by western blot assay; $\alpha$-tubulin was used as a loading control. ${ }^{* * *} p<0.001,{ }^{* *} p<0.01,{ }^{*} p<0.05$. Data was expressed as means $\pm \mathrm{SD}$. Cul4a: cullin 4a; PARP1: poly (ADP-ribose) polymerase-1. 
Cul4a siRNA

Target sequcence

Cul4a

$\alpha$-Tubulin

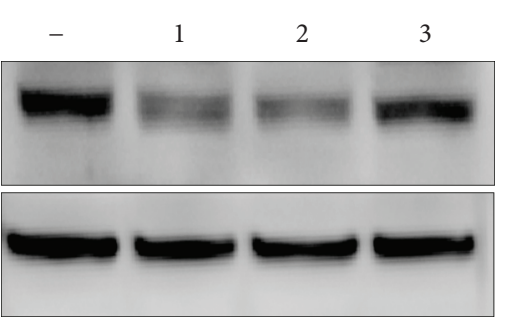

(a)

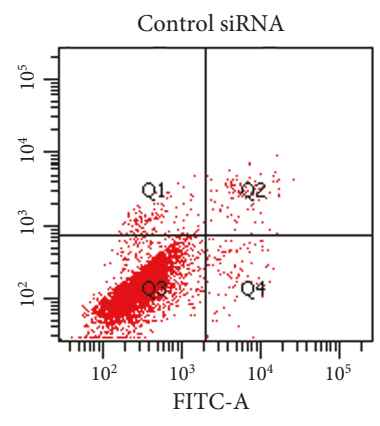

siRNA Cul4a
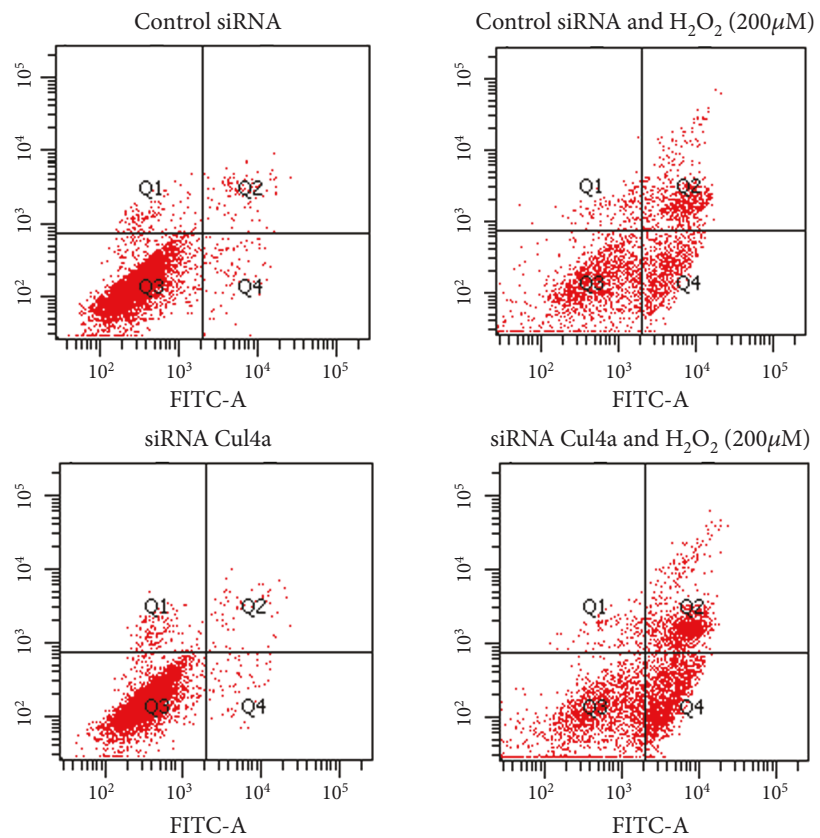

siRNA Cul4a and $\mathrm{H}_{2} \mathrm{O}_{2}(200 \mu \mathrm{M})$

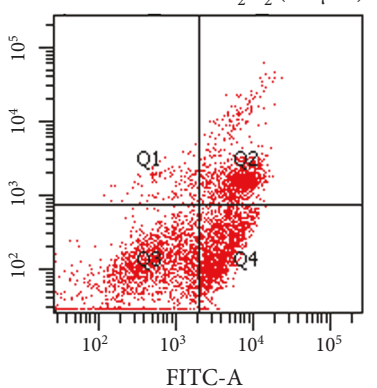

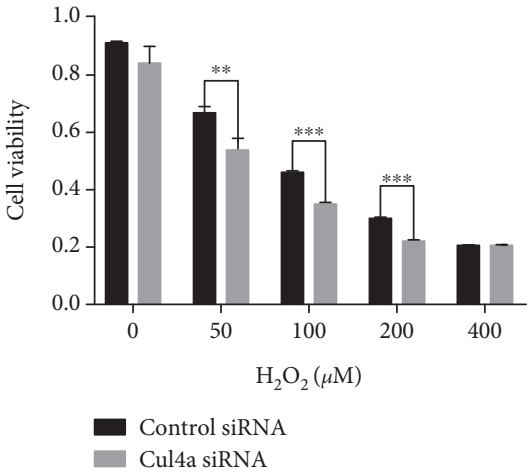

(b)

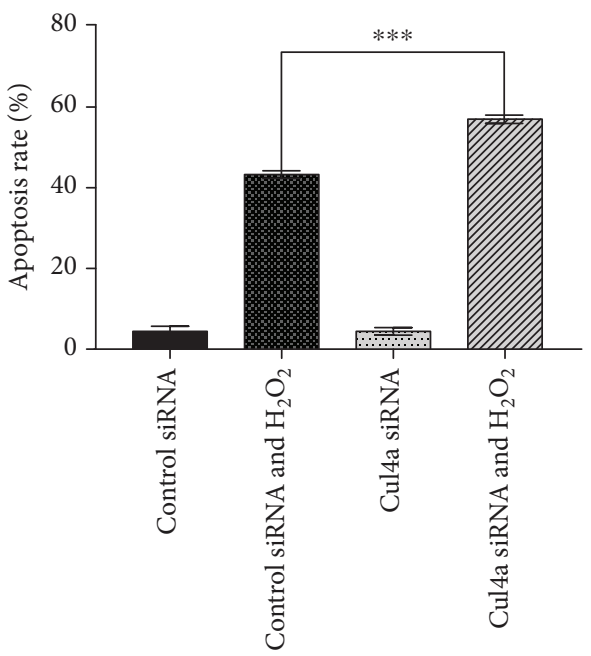

(c)
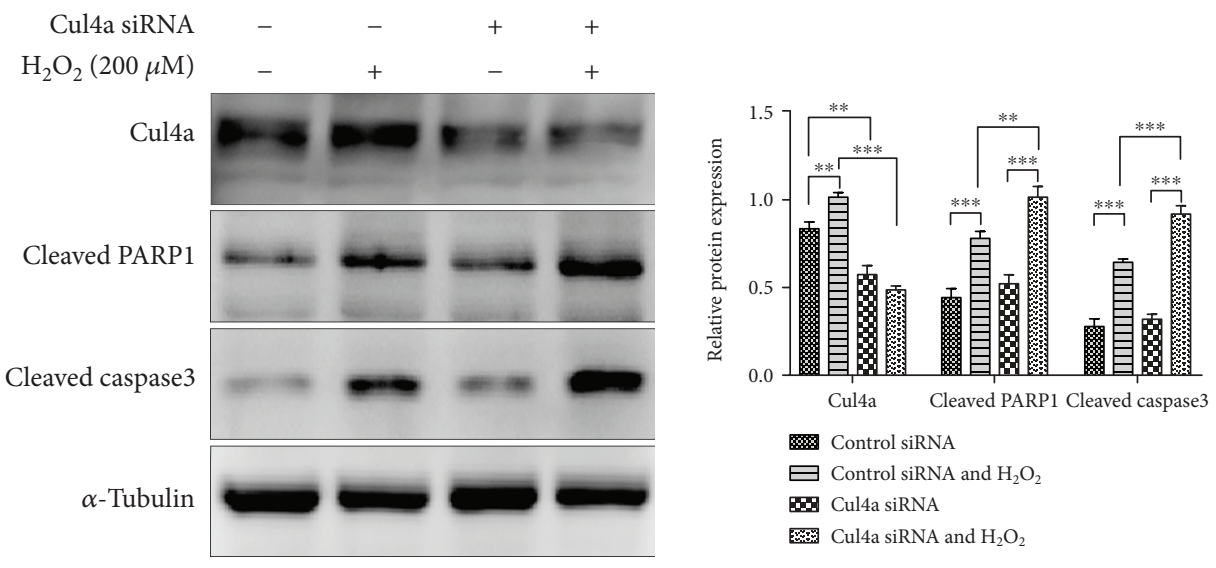

m Control siRNA

$\boxminus$ Control siRNA and $\mathrm{H}_{2} \mathrm{O}_{2}$

Cul4a siRNA

Cul4a siRNA and $\mathrm{H}_{2} \mathrm{O}_{2}$

(d)

Figure 3: Cul4a knockdown aggravated $\mathrm{H}_{2} \mathrm{O}_{2}$-induced $\mathrm{H} 9 \mathrm{c} 2$ cell apoptosis. (a) Efficient Cul4a knockdown was established successfully when compared to control siRNA-transfected cells, and Cul4a siRNA target sequence 2 has the highest knockdown efficiency. (b) H9c2 cells were untreated or treated with $50 \mu \mathrm{M}, 100 \mu \mathrm{M}, 200 \mu \mathrm{M}$, and $400 \mu \mathrm{M} \mathrm{H}_{2} \mathrm{O}_{2}$ for $2 \mathrm{~h}$. CCK-8 assay results showed that Cul4a knockdown increased $\mathrm{H}_{2} \mathrm{O}_{2}$-induced cell cytotoxicity. (c) Flow cytometry Annexin-FITC/PI showed that Cul4a knockdown aggravated $\mathrm{H}_{2} \mathrm{O}_{2}$-induced cell apoptosis. (d) Knockdown Cul4a significantly enhanced $\mathrm{H}_{2} \mathrm{O}_{2}$-induced apoptotic marker proteins cleaved PARP1 and cleaved caspase-3 expression by western blot assay; $\alpha$-tubulin was used as a loading control. ${ }^{* * *} p<0.001,{ }^{* *} p<0.01,{ }^{*} p<0.05$. Data was expressed as means \pm SD. Cul4a: cullin 4a; PARP1: poly (ADP-ribose) polymerase-1. 

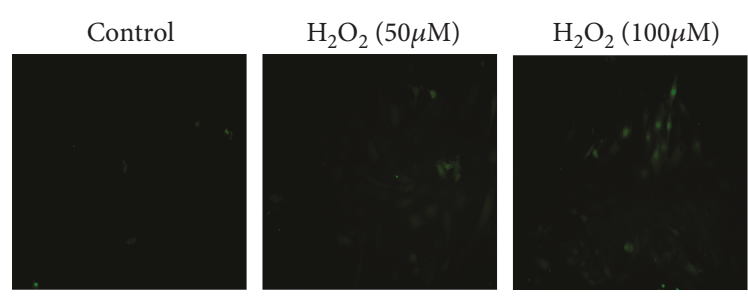

(a)

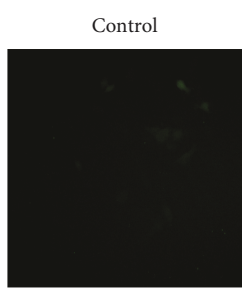

Flag-Cul4a
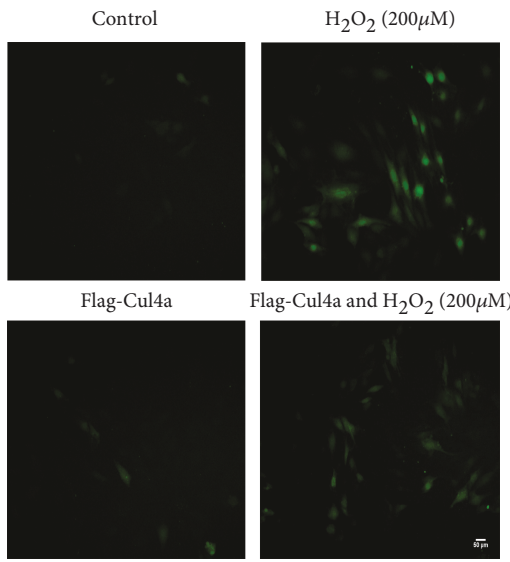

Flag-Cul4a and $\mathrm{H}_{2} \mathrm{O}_{2}(200 \mu \mathrm{M})$

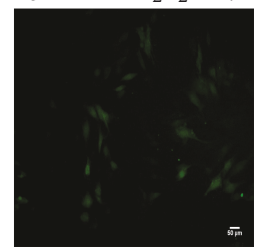

(b)

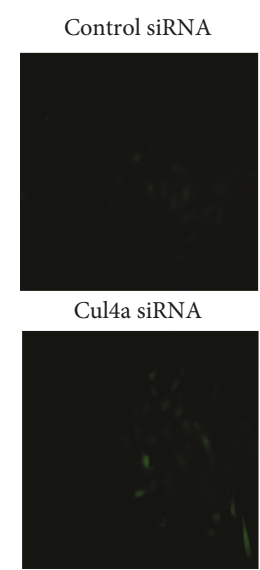

(c)

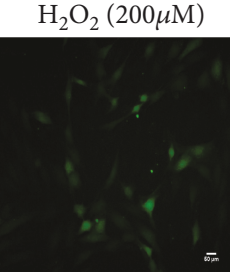

Control siRNA and $\mathrm{H}_{2} \mathrm{O}_{2}$

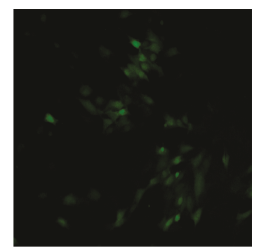

Cul4a siRNA and $\mathrm{H}_{2} \mathrm{O}_{2}$

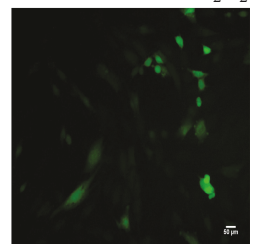

Figure 4: Cul4a influenced $\mathrm{H}_{2} \mathrm{O}_{2}$-induced ROS formation. (a) $\mathrm{H} 9 \mathrm{c} 2$ cells were untreated or treated with $50 \mu \mathrm{M}, 100 \mu \mathrm{M}$, and $200 \mu \mathrm{M} \mathrm{H}_{2} \mathrm{O}_{2}$ for $2 \mathrm{~h}$; ROS production increased gradually by using fluorescence microscopy. (b) Cul4a overexpression inhibited $\mathrm{H}_{2} \mathrm{O}_{2}$-induced ROS production by using fluorescence microscopy. (c) Cul4a knockdown enhanced $\mathrm{H}_{2} \mathrm{O}_{2}$-induced ROS production by using fluorescence microscopy. Scale bar $=50 \mu \mathrm{m}$. Cul4a: cullin $4 \mathrm{a}$.

\section{Results}

3.1. $\mathrm{H}_{2} \mathrm{O}_{2}$ Increased Cul4a and Apoptosis-Related Protein and Dramatically Decreased the Viability of $\mathrm{H} 9 \mathrm{c} 2$
Cardiomyocytes. Given that few studies had demonstrated how Cul4a changed in oxidative stress-induced myocardial apoptosis, we took the initiative to determine the trend of the Cul4a expression in cardiomyocytes treated with $\mathrm{H}_{2} \mathrm{O}_{2}$ at a concentration of $0,50,100,200$, and $400 \mu \mathrm{M}$ for 2 hours. As shown in Figure 1, the expression of Cul4a, apoptotic marker proteins cleaved PARP1 and cleaved caspase3, increased obviously with concentration. Moreover, the cell viability notably decreased, and the apoptosis rate increased. Two hours after the treatment of $200 \mu \mathrm{M} \mathrm{H}_{2} \mathrm{O}_{2}$, immunofluorescence imaging analysis was used to determine the Cul4a expression of the level and localization. Therefore, our results revealed that Cul4a may be crucial in oxidative stressinduced myocardial injury.

\subsection{Cul4a Overexpression Inhibited $\mathrm{H}_{2} \mathrm{O}_{2}$-Induced} Cytotoxicity, Apoptosis, and Apoptotic Marker Protein Expression. To validate the effect of Cul4a in $\mathrm{H}_{2} \mathrm{O}_{2}$-induced myocardial injury, $\mathrm{H} 9 \mathrm{c} 2$ cardiomyocytes were handled with Flag-Cul4a plasmid or empty plasmid for 48 hours, and then oxidative stress was induced with $200 \mu \mathrm{M} \mathrm{H}_{2} \mathrm{O}_{2}$ for 2 hours. As shown in Figure 2, Cul4a overexpression inhibited $\mathrm{H}_{2} \mathrm{O}_{2}$-induced cytotoxicity, apoptosis, and apoptotic marker protein expression. Thus, the outcome indicated that Cul4a overexpression significantly inhibited oxidative stressinduced myocardial apoptosis.

3.3. Cul4a Knockdown Raised $\mathrm{H}_{2} \mathrm{O}_{2}$-Induced Cytotoxicity, Apoptosis, and Apoptotic Marker Protein Expression. In order to further explore the effects of Cul4a knockdown on $\mathrm{H}_{2} \mathrm{O}_{2}$ induced injury, we practiced siRNA knockdown of Cul4a. Cul4a siRNA target sequence 1,2 , and 3 were synthesized in order to choose the optimal efficiency. Figure 3(a) showed, comparing to control siRNA-transfected cells, Cul4a knockdown was established successfully, and we chose Cul4a siRNA target sequence 2 for subsequent experiments owing to the highest knockdown efficiency. Then, we used control siRNA and Cul4a sequence 2 to transfect H9c2 cells for 48 hours, and subsequently, oxidative stress was induced with $200 \mu \mathrm{M} \mathrm{H}_{2} \mathrm{O}_{2}$ for 2 hours. Figure 3 demonstrated that Cul4a knockdown raised $\mathrm{H}_{2} \mathrm{O}_{2}$-induced cell cytotoxicity, apoptosis, and apoptotic marker proteins cleaved PARP1 and cleaved caspase 3 expression. Therefore, these results proved Cul4a suppression promoted oxidative stress-induced myocardial apoptosis.

3.4. Cul4a Influenced $\mathrm{H}_{2} \mathrm{O}_{2}$-Induced ROS Formation. To demonstrate the effects of Cul4a on oxidative stress, we exercised a ROS assay. Firstly, we verified that $\mathrm{H}_{2} \mathrm{O}_{2}$ can induce ROS production. We treated cardiomyocytes with $\mathrm{H}_{2} \mathrm{O}_{2}$ at a concentration of $0,50,100$, and $200 \mu \mathrm{M}$ for 2 hours; the results in Figure 4(a) showed that the expression of ROS formation increased. Next, we established Cul4a overexpression 


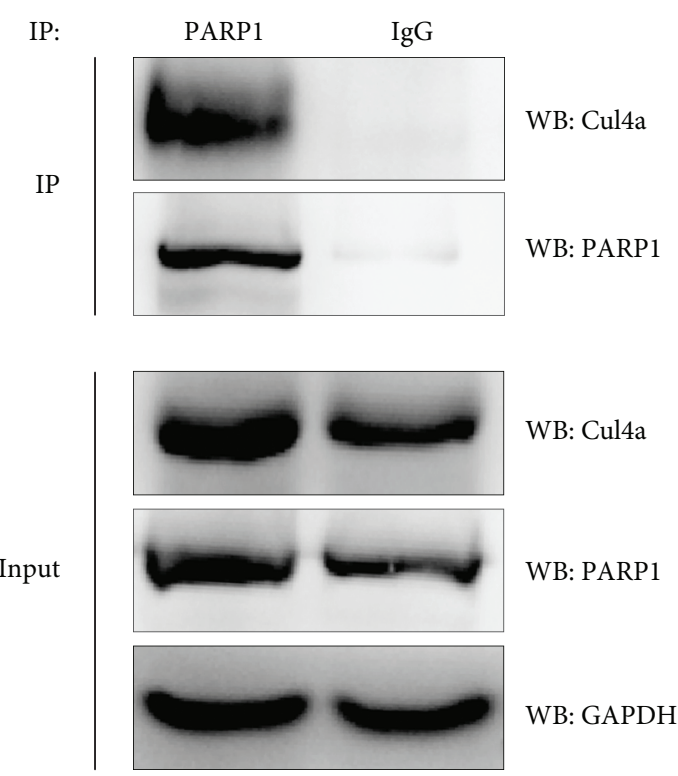

(a)

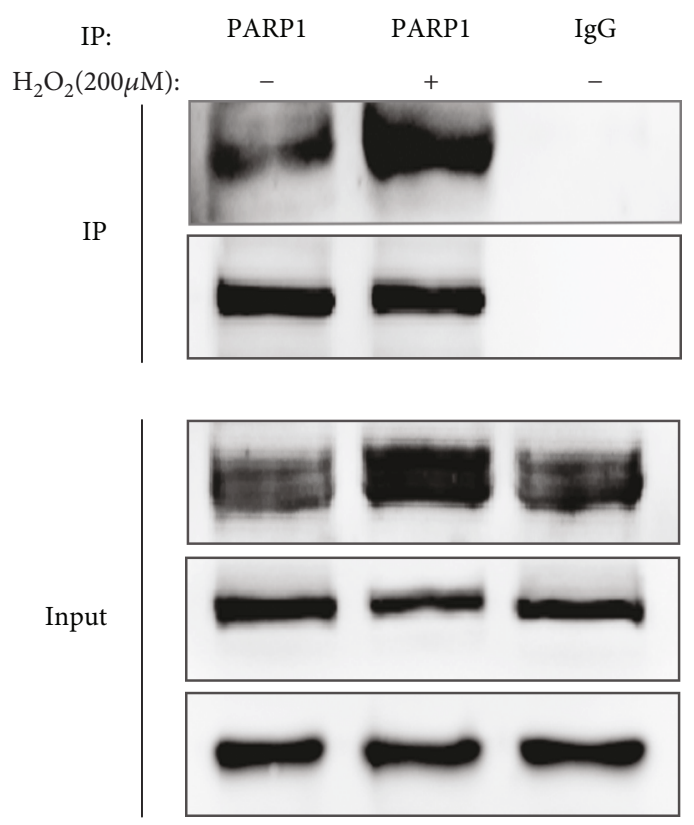

(c)

WB: PARP1

WB: Cul4a

WB: PARP

WB: GAPDH

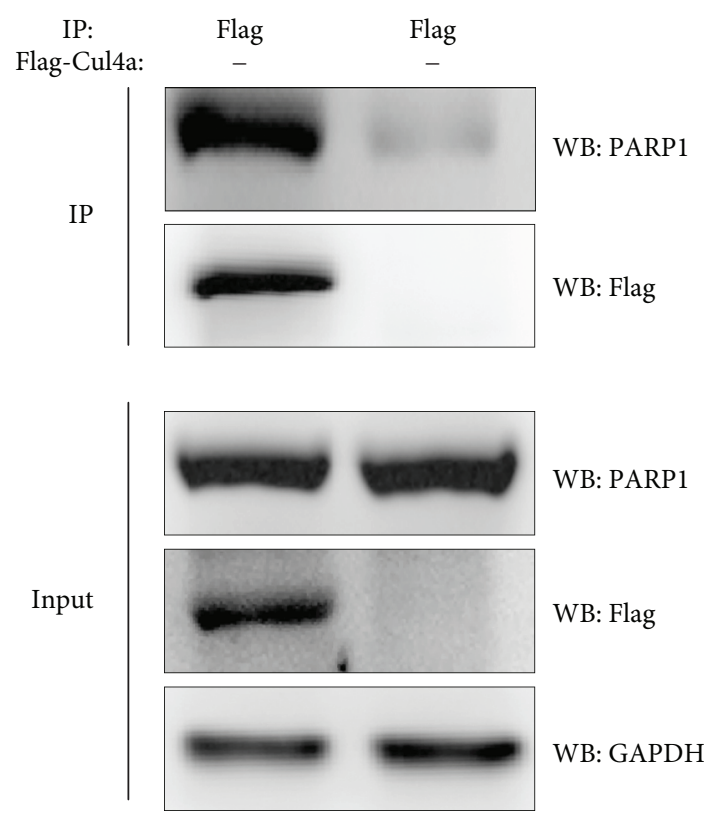

(b)

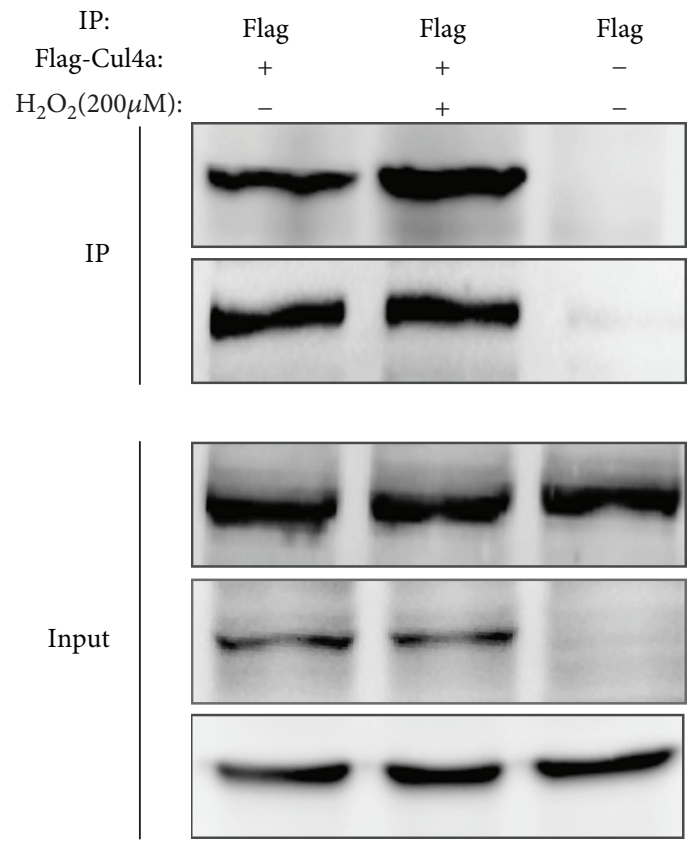

WB: PARP1

(d)

FIGURE 5: PARP1 was a novel Cul4a-interacting protein, and the interaction was enhanced under oxidative stress. (a) Coimmunoprecipitation (co-IP) and western blotting (IP-western) using anti-PARP1 antibody or negative control IgG and Protein A/G immunoprecipitation magnetic beads followed by anti-Cul4a western blot were performed to identify endogenous interaction between PARP1 and Cul4a. (b) Anti-Flag antibody and Protein A/G immunoprecipitation magnetic beads followed by anti-PARP1 western blot were performed to identify semiexogenous interaction between Flag-Cul4a and PARP1. (c) Endogenous interaction between PARP1 and Cul4a was enhanced by treatment of $200 \mu \mathrm{M} \mathrm{H}_{2} \mathrm{O}_{2}$ for $2 \mathrm{~h}$, which were evaluated by coimmunoprecipitation using anti-PARP1 antibody. (d) Semiexogenous interaction between Flag-Cul4a and PARP1 was enhanced by treatment of $200 \mu \mathrm{M} \mathrm{H}_{2} \mathrm{O}_{2}$ for $2 \mathrm{~h}$, which were evaluated by coimmunoprecipitation using anti-Flag antibody. GAPDH was used as a loading control. Cul4a: cullin 4a; PARP1: poly (ADP-ribose) polymerase-1; GAPDH: glyceraldehyde-3-phosphate dehydrogenase.

and knockdown and treated the cells with $200 \mu \mathrm{M} \mathrm{H}_{2} \mathrm{O}_{2}$ for $2 \mathrm{~h}$; it was found that Cul4a overexpression hindered ROS generation as shown in Figure 4(b) and Cul4a suppression promoted ROS production as shown in Figure 4(c). This suggested that Cul4a could affect $\mathrm{H}_{2} \mathrm{O}_{2}$-induced ROS production, thereby mitigating cell damage caused by oxidative stress.

\subsection{Identification of PARP1 as a New Cul4a-Binding Protein} and the Interaction Was Enhanced under Oxidative Stress. 


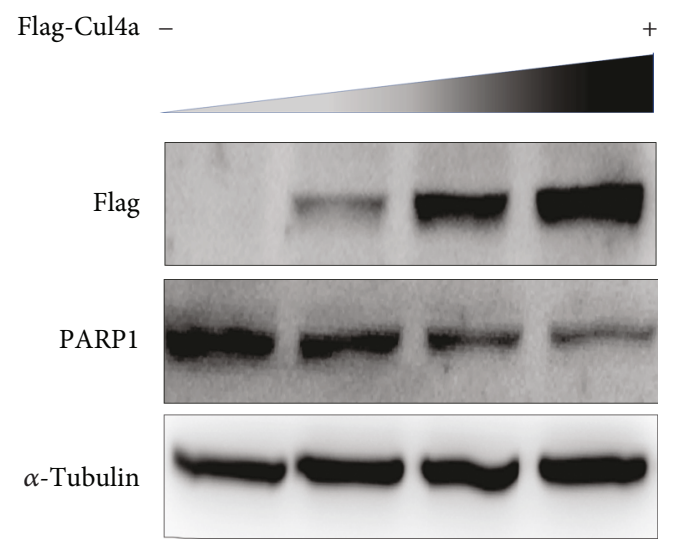

(a)

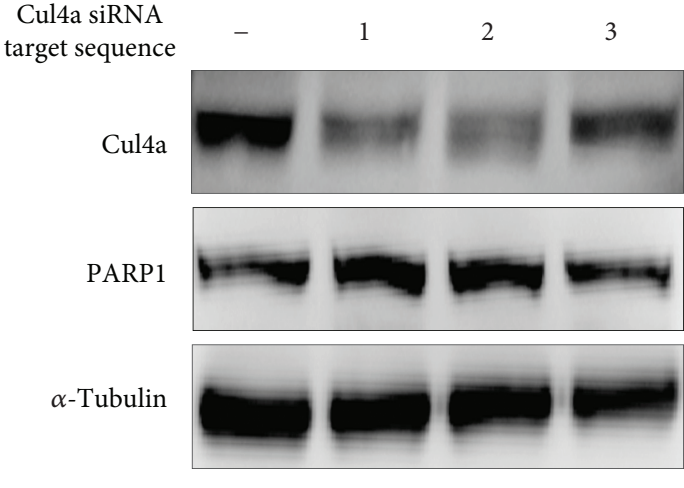

(b)

FIgURE 6: Cul4a can decrease the expression of PARP1. (a) Cul4a gradient overexpress with different amounts of plasmid in H9c2 cells, the expression of PARP1 decreased. (b) Knockdown Cul4a with control siRNA and Cul4a siRNA target sequence 1, 2, and 3, the expression of PARP1 with Cul4a siRNA target sequence 1 and 2 increased. $\alpha$-Tubulin was used as a loading control. Cul4a: cullin 4a; PARP1: poly (ADPribose) polymerase-1.

The above results indicated Cul4a operates positive effect in oxidative stress-induced myocardial cell injury. But the mechanism remained not clear. We identified PARP1 was a new Cul4a-interacting protein through applying coimmunoprecipitation. As shown in Figure 5, endogenous and semiexogenous Cul4a interacted with PARP1, and the interaction was enhanced after using by $\mathrm{H}_{2} \mathrm{O}_{2}$ treatment. Thus, it revealed apoptosis-related protein PARP1 can serve as a new binding protein of Cul4a, and the interaction was strengthened under oxidative stress. These results implied Cul4a may reduce damage by interacting with overactivated PARP1 in oxidative stress-induced myocardial cell injury.

3.6. Confirmed That Cul4a Could Decrease the Expression of PARP1. Proceeding to sufficiently examine the effect of Cul4a and PARP1 binding on PARP1, we established Cul4a gradient overexpression with different amounts of plasmid in H9c2 cells. The expression of PARP1 was detected by western blot. As shown in Figure 6, with the increase in the expression of Cul4a, the PARP1 expression decreased, while the knockdown Cul4a showed the opposite effect, which implied that Cul4a can reduce PARP1.

\section{Discussion}

We discovered Cul4a as a novel protein that was involved in oxidative stress-induced myocardial apoptosis. Moreover, overexpression of Cul4a could obviously attenuate oxidative stress-induced cardiomyocyte apoptosis, and the knockdown of Cul4a showed just the opposite effect. We also found that Cul4a was a novel binding protein of PARP1 and reduced the expression of PARP1.

PARP1 is activated in order to repair DNA damage during cell damage; however, hyperactive PARP1 plays a negative role in cell apoptosis and even death after damage [12]. A study from Fouquerel et al. showed that PARP1 hyperactivation results in reduced glycolysis and ATP loss [13]. PARP1 activity has also been suggested to reduce respiration by direct influence on the enzymatic activity of mitochondrial proteins [14]. In oxidative stress, activated PARP1 can increase ROS production, which triggered the cell death [15] and can consume large amounts of ATP, ultimately leading to apoptosis [16]. PARP1 is widely involved in oxidative stress-related cardiovascular diseases [6, 7]. Recent studies have shown that hyperactive PARP1 exacerbates ischemic reperfusion injury in vivo and in vitro experiment. PARP1 activation undermines cell survival by preventing mitochondrial recovery after $\mathrm{mPTP}$ opening early in reperfusion [17], and PARP1 inhibitors can significantly alleviate oxidative stress-induced reperfusion injury [8, 18]. Hence, PARP1 plays an important role in regulating cardiovascular diseases. We identified PARP1 as a novel binding protein of Cul4a ubiquitin ligase in physiological state, and the interaction is significantly increased in oxidative stress state. It implies that Cul4a is a novel protective factor in oxidative stress-induced myocardial injury by interacting with PARP1 and degrading it.

For the first time, we found that Cul4a was elevated in oxidative stress-induced myocardial apoptosis. Further, Cul4a overexpression could reduce the damage, whereas knockdown could aggravate it. At the same time, Cul4a also influenced the amount of ROS. Cul4a is an E3 ubiquitin ligase of significance in DNA replication, cell cycle regulation, and genomic instability [11]. Cul4a is abnormally expressed in various cancers, and many studies have shown that it is closely related to the proliferation and invasion of lung cancer [19], gastric cancer [20], and prostate cancer [21]. Cul4a is vital for cell survival. Waning et al. reported that the deletion of Cul4A can increase the expression of Cul4A ligase target Cdt 1 and P27, which results in apoptosis [22]. In addition, Cul4A can be central in the regulation of the cellular levels of PNKP and hence in the repair of oxidative DNA damage [23]. There has been a report that zebrafish Cul4a modulates cardiac and forelimb development by upregulating the tbx5a expression [24]. However, the role of Cul4a in cardiovascular disease has been little reported. Cul4a acts as the core of the CRLs E3 ubiquitin ligase, and its complex can bind multiple substrates [9]. Here, we 
reported that a new binding protein PARP1 could be combined with Cul4a, and in the case of oxidative stress, this binding was significantly enhanced. We also found the regulation of Cul4a controlled the expression of PARP1. Based on the information above, we hypothesized that Cul4a can be elevated and inhibit apoptosis by binding PARP1 to degrade excess PARP1. These findings may provide a target for the treatment of reperfusion injury.

Our study shows that Cul4a is involved in oxidative stress-induced myocardial apoptosis and PARP1 is a new binding protein to Cul4a ubiquitin ligase, which may become a new therapeutic target in reperfusion injury. However, we acknowledge that there are some limitations in our study. Cul4a knockdown or Cul4a overexpression mice have not been performed to analyze the effect of $\mathrm{Cul} 4 \mathrm{a}$ on reperfusion injury. In addition, although our study is the first to report that Cul4a is involved in oxidative stress-induced myocardial injury, whether Cul4a is associated with other cardiovascular diseases is still unclear. Moreover, as the fact has been confirmed that Cul4a degrades target proteins through ubiquitin ligase, it is attractive to explore the detailed mechanism about how Cul4a degraded PARP1 by ubiquitination. Therefore, further experiments are needed.

\section{Conclusions}

We have demonstrated that Cul4a is involved in oxidative stress-induced myocardial cell apoptosis and PARP1 is a novel interaction protein for Cul4a. When Cul4a is overexpressed, PARP1 decreases, so does the generation of ROS, which can obviously attenuate oxidative stress-induced cardiomyocyte injury.

\section{Data Availability}

The data used to support the findings of this study are included within the article.

\section{Conflicts of Interest}

The authors declare that there is no conflict of interest regarding the publication of this paper.

\section{Acknowledgments}

This study was supported by grants from the 64th Batch of China Postdoctoral Science Fund Project, Grant \#2018M641750.

\section{References}

[1] National Center for Cardiovascular Diseases of China, Report on Cardiovascular Disease in China (2017), Encyclopedia of China Publishing House, 2018.

[2] H. K. Eltzschig and T. Eckle, "Ischemia and reperfusion-from mechanism to translation," Nature Medicine, vol. 17, no. 11, pp. 1391-1401, 2011.

[3] G. M. Fröhlich, P. Meier, S. K. White, D. M. Yellon, and D. J. Hausenloy, "Myocardial reperfusion injury: looking beyond primary PCI," European Heart Journal, vol. 34, no. 23, pp. 1714-1722, 2013.

[4] M. N. Sack, F. Y. Fyhrquist, O. J. Saijonmaa, V. Fuster, and J. C. Kovacic, "Basic biology of oxidative stress and the cardiovascular system: part 1 of a 3-part series," Journal of the American College of Cardiology, vol. 70, no. 2, pp. 196-211, 2017.

[5] M. Y. Kim, S. Mauro, N. Gévry, J. T. Lis, and W. L. Kraus, "NAD"-dependent modulation of chromatin structure and transcription by nucleosome binding properties of PARP-1," Cell, vol. 119, no. 6, pp. 803-814, 2004.

[6] C. Szabó, "Cardioprotective effects of poly(ADP-ribose) polymerase inhibition," Pharmacological Research, vol. 52, no. 1, pp. 34-43, 2005.

[7] L. Virág and C. Szabó, "The therapeutic potential of poly(ADP-ribose) polymerase inhibitors," Pharmacological Reviews, vol. 54, no. 3, pp. 375-429, 2002.

[8] P. Pacher and C. Szabó, "Role of poly(ADP-ribose) polymerase 1 (PARP-1) in cardiovascular diseases: the therapeutic potential of PARP inhibitors," Cardiovascular Drug Reviews, vol. 25, no. 3, pp. 235-260, 2007.

[9] J. Hannah and P. Zhou, "Distinct and overlapping functions of the cullin E3 ligase scaffolding proteins CUL4A and CUL4B," Gene, vol. 573, no. 1, pp. 33-45, 2015.

[10] P. Sharma and A. Nag, "CUL4A ubiquitin ligase: a promising drug target for cancer and other human diseases," Open Biology, vol. 4, no. 2, article 130217, 2014.

[11] S. Jackson and Y. Xiong, "CRL4s: the CUL4-RING E3 ubiquitin ligases," Trends in Biochemical Sciences, vol. 34, no. 11, pp. 562-570, 2009.

[12] A. Chiarugi and M. A. Moskowitz, "PARP-1-a perpetrator of apoptotic cell death?," Science, vol. 297, no. 5579, pp. 200201, 2002.

[13] E. Fouquerel, E. M. Goellner, Z. Yu et al., "ARTD1/PARP1 negatively regulates glycolysis by inhibiting hexokinase 1 independent of $\mathrm{NAD}^{+}$depletion," Cell Reports, vol. 8, no. 6, pp. 1819-1831, 2014.

[14] P. Lu, A. Kamboj, S. B. Gibson, and C. M. Anderson, "Poly (ADP-ribose) polymerase-1 causes mitochondrial damage and neuron death mediated by Bnip3," The Journal of Neuroscience, vol. 34, no. 48, pp. 15975-15987, 2014.

[15] E. Hocsak, V. Szabo, N. Kalman et al., "PARP inhibition protects mitochondria and reduces ROS production via PARP1-ATF4-MKP-1-MAPK retrograde pathway," Free Radical Biology and Medicine, vol. 108, pp. 770-784, 2017.

[16] A. Joshi, R. Iyengar, J. H. Joo et al., "Nuclear ULK1 promotes cell death in response to oxidative stress through PARP1," Cell Death and Differentiation, vol. 23, no. 2, pp. 216-230, 2016.

[17] J. M. Schriewer, C. B. Peek, J. Bass, and P. T. Schumacker, "ROS-mediated PARP activity undermines mitochondrial function after permeability transition pore opening during myocardial ischemia-reperfusion," Journal of the American Heart Association, vol. 2, no. 2, 2013.

[18] E. Szabados, P. Literati-Nagy, B. Farkas, and B. Sumegi, "BGP15, a nicotinic amidoxime derivate protecting heart from ischemia reperfusion injury through modulation of poly(ADP-ribose) polymerase," Biochemical Pharmacology, vol. 59, no. 8, pp. 937-945, 2000.

[19] L. Jia, F. Yan, W. Cao et al., "Dysregulation of CUL4A and CUL4B ubiquitin ligases in lung cancer," Journal of Biological Chemistry, vol. 292, no. 7, pp. 2966-2978, 2017. 
[20] Y. Wang, M. Wen, Y. Kwon et al., "CUL4A induces epithelialmesenchymal transition and promotes cancer metastasis by regulating ZEB1 expression," Cancer Research, vol. 74, no. 2, pp. 520-531, 2014.

[21] S. Ren, C. Xu, Z. Cui et al., "Oncogenic CUL4A determines the response to thalidomide treatment in prostate cancer," Journal of Molecular Medicine, vol. 90, no. 10, pp. 1121-1132, 2012.

[22] D. L. Waning, B. Li, N. Jia et al., "Cul4A is required for hematopoietic cell viability and its deficiency leads to apoptosis," Blood, vol. 112, no. 2, pp. 320-329, 2008.

[23] J. L. Parsons, S. V. Khoronenkova, I. I. Dianova et al., "Phosphorylation of PNKP by ATM prevents its proteasomal degradation and enhances resistance to oxidative stress," Nucleic Acids Research, vol. 40, no. 22, pp. 11404-11415, 2012.

[24] X. Zhao, B. Jiang, H. Hu et al., "Zebrafish cul4a, but not cul4b, modulates cardiac and forelimb development by upregulating tbx5a expression," Human Molecular Genetics, vol. 24, no. 3, pp. 853-864, 2015. 


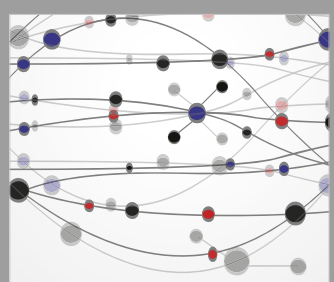

The Scientific World Journal
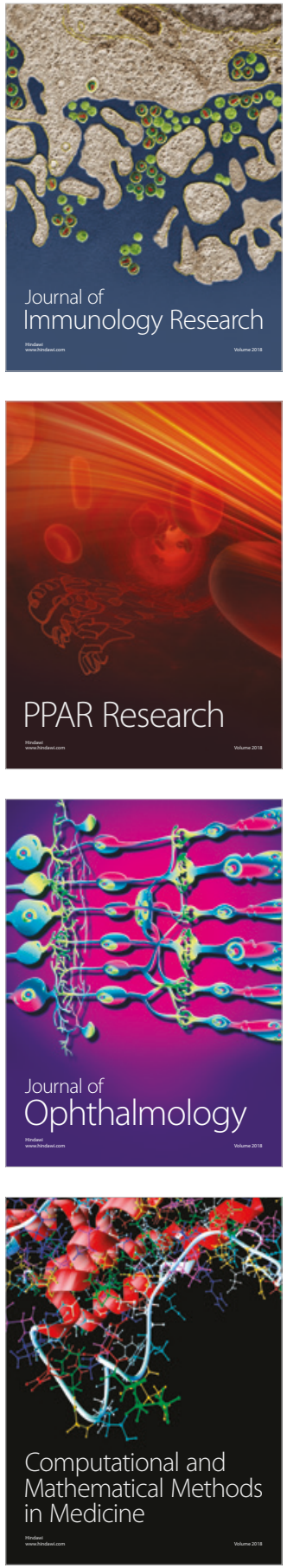

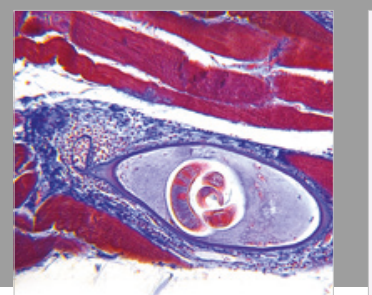

Gastroenterology Research and Practice

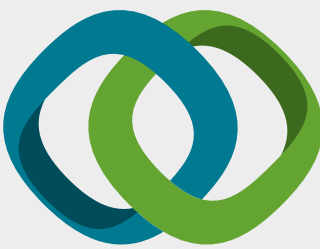

\section{Hindawi}

Submit your manuscripts at

www.hindawi.com
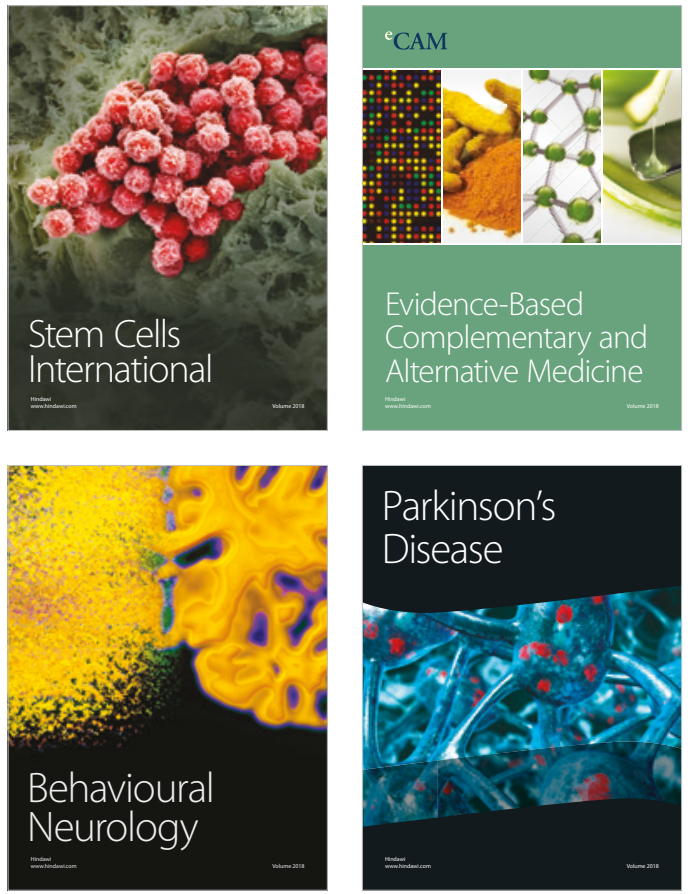

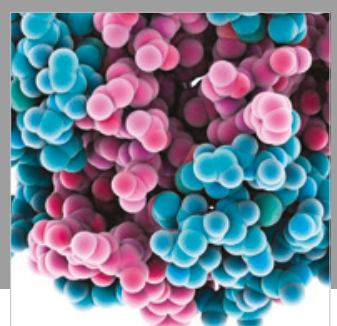

ournal of

Diabetes Research

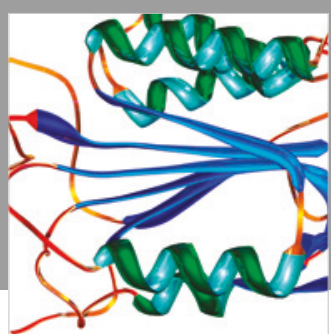

Disease Markers
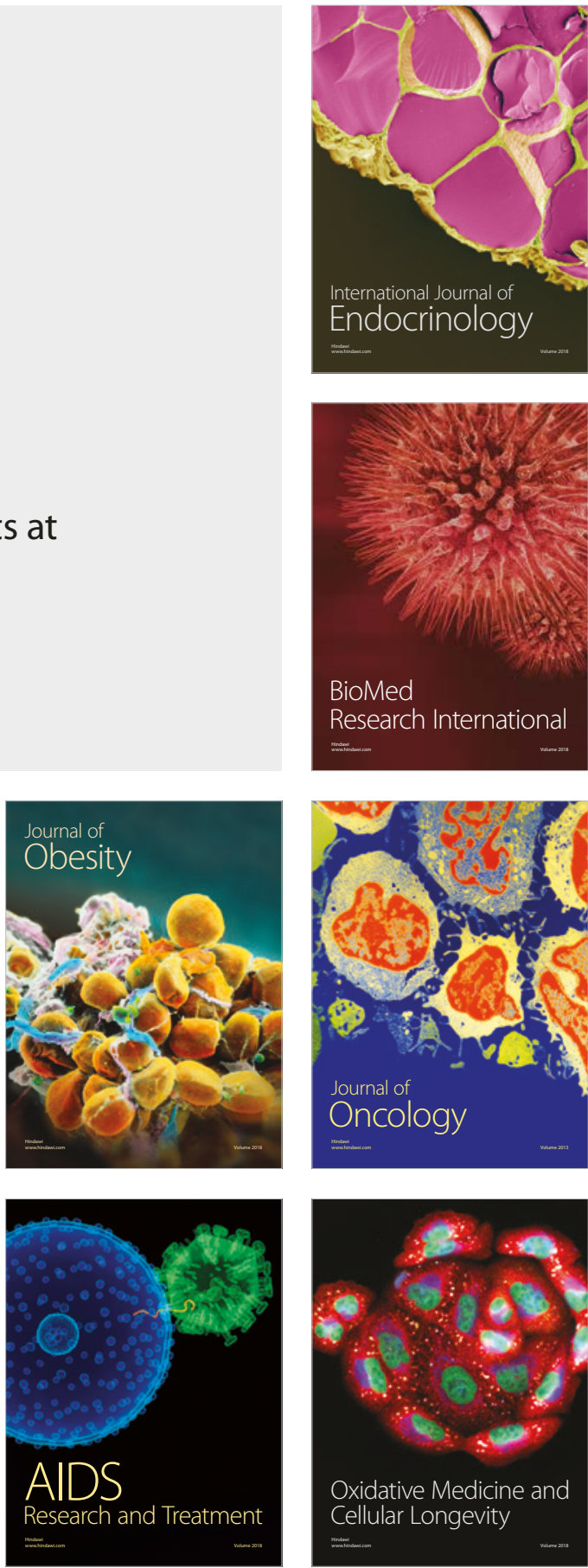